\title{
Determinants of Venture Capital Supply in Sub-Saharan Africa
}

\author{
Olabanji Oni \\ University of Fort Hare, South Africa \\ ooni@ufh.ac.za
}

\begin{abstract}
The purpose of this paper is to determine the variables that influence venture capital supply in Sub-Sahara Africa. The study developed econometric models and examined a 10-year period (2006 to 2015) pertaining to eight (8) Sub-Sahara African countries namely: Botswana, Ivory Coast, Ghana, Kenya, Mauritius, Nigeria, South Africa and Uganda. The empirical model includes six determinants (initial public offering, market capitalisation, unemployment rate, foreign direct investment inflow, inflation rate and trade openness). Secondary data was utilised for the study. The primary sources of data were the World Bank Development indicators and Preqin data base. All the statistical analyses in the study were performed using E-views version 8. Panel data models of pooled, fixed and random effects were employed. The results suggest that there is a significant positive relationship between initial public offering, market capitalisation and venture capital supply. Second, there is no significant relationship between unemployment rate, foreign direct investment inflows, trade openness and venture capital supply. Based on the empirical findings, this study recommends that Sub-Sahara African governments should attempt to develop their economies by improving infrastructure and corporate governance. There is also a need for African countries to develop the equity market.
\end{abstract}

Key words: Venture Capital Supply, Determinants of Venture Capital, Venture Capital, Sub-Sahara Africa, Africa

\section{Introduction}

Venture capital investments are investments made at various phases of the business life cycle including the start-up and expansion phase right up to preparation for exit from the investment via buyout or initial public offering (Solnik \& McLeavey, 2009). Venture capital and private equity are identical and used similarly in various studies. There is a difference between formal from informal venture capitalist. Formal venture investment is a company that functions as an asset group and an informal venture capital are angel shareholders who are affluent people considering to finance novel projects that has high probability of growing (Kuratko \& Hodgetts, 2007; Nieman, 2006; Chemmanur \& Chen, 2006). Over the past ten years, while much of the mature markets have witnessed recession, Africa has received a lot of interest from venture capitalist (AVCA, 2013). Emerging Markets Private Equity Association (2013) reported that SubSahara Africa is for the first time the most attractive emerging market for investors. Johnson (2010) found that despite the financial crisis experienced in 2008, the venture capital industry experienced an increase in market yield in Africa. Africa venture capital posted $11.2 \%$ annualised return over the past 10 years (Ventures Africa, 2013). There is an increase in investors' confidence because of the performance of emerging market venture capitalists in Sub-Sahara Africa (Lebus, 2013).

Studies on the determinants of venture capital supply have investigated many variables with conflicting conclusions. In South Africa, Msweli and Oni (2014) found three factors that influence venture capital supply namely; (1) micro small and medium enterprise size, (2) the degree of industrial development and (3) portion of natural resource addition to the gross domestic product. Additionally, Van Deventer and Mlambo (2009) establish that the three main measures for venture investors in South Africa are; (1) the capitalist's trustworthiness and truthfulness, (2) an excellent anticipated market condition and (3) a good discount rate. Adongo (2011) emphasised the importance of the institutional environment underlying initial public offerings, efficacy of equity market, bond market, currency market, commodity market and derivatives as well as the uncertainty level in the market place. In Ghana, Agyeman (2010) found that venture capital is affected by a number of factors including: (1) limited fund raising opportunities and absence of exit opportunities because of dormant initial public offering setting; (2) deficiency of sector rules and controlling framework; (3) non-existence of research provision for the sector and (4) bad record management system of small and medium enterprises (SMEs), which leads to information asymmetry. This study focuses on six variables that can affect venture capital supply. These are initial public offering, market capitalisation, unemployment rate, foreign direct investment inflows, inflation rate and trade openness. An understanding of the determinants of 
venture capital supply will assist governments and policymakers to formulate and implement policies for attracting venture capitalists.

\section{Literature Review}

The theoretical foundation of venture capital supply can be approached through the capital structure theory.

Capital structure theory: Harris and Raviv (2012) explained that the theoretical philosophies fundamental for capital structure consist of Modigliani and Miller (1958) trade-off theory, Jensen and Meckling (1976) agency theory and Myers (1984) pecking order theory. The trade-off theory points out that companies can be financed using equity finance and debt finance. There are two main types of trade-off theories: (1) tax/bankruptcy trade off theory and (2) agency theory. This study argues that debt attracts interests and leads to a financial obligation to pay principal and interests. It will be very difficult for a company to pay off debts when liabilities are greater than assets. This makes debt finance unattractive and firms will have to look for an alternative source of finance, for example equity finance. One major source of equity capital is venture capital. The agency theory by Jensen and Meckling (1976) argues that an ideal capital structure can be achieved from a sacrifice between debt and equity or hybrid finance. The pecking order theory, as explained by Myers (1984) suggests that there is no well-defined optimal capital structure. The pecking order theory points out that there are three sources of finance: (1) internal sources of funding; (2) debt financing; and (3) equity financing. This study argues that the external equity finance (venture capital finance) is collateral and interest free and can be used to finance growth. This argument is buttressed by the fact that debt finance needs collateral and attracts interest and internal equity finance is limited in financing growth (Iqbal et al., 2012).

Initial public offering and venture capital supply: Literature on the association between IPO and venture capital supply is inconclusive. The seminal work of Black and Gilson (1998) debated that a well-built share market that allows venture investors to withdraw via IPO is critical to the survival of an exciting venture capital marketplace. Their study emphasised that the core risk encountered by venture investors is the risk of no return on investment. Additionally, the study found that an exit tool is significant for venture capitalist for two (2) motives; (1) it offers a monetary benefit for share rewarded directors to increase effort and (2) it provides the directors a call option on control of the company, because venture capital investors surrender control at the time of IPO. Building on Black and Gilson (1998), Jeng and Wells (2000) which extended the work of Black and Gilson (1998) found that IPO remain the most important determinant of venture capital supply. In addition, their study argued that the coefficient of IPOs is positive at the later stage because venture capital investments often end up as IPOs. This means increased size of IPOs should have a direct effect on the venture capital supply at the later stage. On the other hand, Chang (2004) study found a significant positive relationship between IPO and venture capital supply at the early stage of investment.

Contrary to the above, IPOs have no impact on early stage venture capital investment across countries, but are a significant determinant for the later stage venture capital investment. Gompers and Lerner (1998) as well as Jeng and Wells (2000) found that there is no statistically significant relationship between IPO and venture capital supply at the early stage. These findings are in conflict with Da Rin, Niconda and Sembenelli (2006) that found a positive relationship between the size of IPOs market and the amount of funds available for venture capital. Furthermore, Banerjee (2008) in India found that there is a positive association between IPO and venture capital supply. A recent study by Félix et al. (2013) found that, there is a statistically significant positive relationship between IPO and venture capital supply and concluded that among all the authors indicated above the only previous study that obtained a statistically positive relationship between IPO and venture capital supply at the later stage was Jeng and Wells (2000). Ecer and Khalid (2013) discovered that there is a significant negative relationship between IPO and venture capital supply for High technology firms and a significant positive relationship between IPO and venture capital supply for Low technology firms. Henderson and Newell (2011) in a study conducted in USA found that a reduction in IPO has a negative effect on venture capital supply. However, the contradictory and inconclusive opinions identified above by the literature necessitate an investigation into the relationship between IPO and venture capital supply in the context of Sub-Sahara Africa. This study argues that there is a positive relationship between higher levels of IPO and venture capital supply. 
Market capitalisation and venture capital supply: Literature on the link between market capitalisation and venture capital supply is inconclusive. The seminal work of Gompers and Lerner (1999); Romain and de la Potterie (2004) as well as Félix et al. (2013) found that there is a significant positive association between market capitalisation and venture capital supply. Furthermore, Bonini and Alkan (2009) argued that there is a positive association between market capitalisation and venture capital supply. Literature has found that an increase in market capitalisation is expected to create a more favourable environment for investors to fund venture capital. Clarysse, Knockaent and Wright (2009) explained that the amount of early stage venture capital supply is determined by stock market capitalisation. Kelly (2012) identified the positive impact of market capitalisation on venture capital investments and points out that an increase in market capitalisation results in an increase of available funds for venture capital. Furthermore, Cherif and Gazder (2011) found that there is a positive association between market capitalisation and venture capital supply. However, Jeng and Wells (2000) found that there is no connection between market capitalisation and venture capital supply. A study by Diaconu (2012) in Romania that used an econometric model of macro-economic variables found that there is no significant relationship between market capitalisation and venture capital supply. Based on the foregoing discussion, this study argues that higher market capitalisation creates a favourable environment for investors and increases investors' confidence (Muneer et al., 2013). It is expected that higher market capitalisation will lead to more commitment of funds by investors into the venture capital market. It is on this basis that this study argues that there is a significant positive relationship between market capitalisation and venture capital supply. This study argues that there is a positive relationship between higher levels of market capitalisation and venture capital supply.

Unemployment and venture capital supply: Unemployment is a major economic problem in Sub-Sahara Africa. Mohr and Fourie (2014) explained that the costs of unemployment are significant and includes: (1) loss of income; (2) shock and frustration; and (3) hunger, cold, ill health and even death. World Bank (2012) reported that the unemployment rate in Sub-Sahara Africa is higher than that of developed countries. Few studies investigated the link between unemployment and venture capital supply. A study by Diaconu (2012) found no relationship between unemployment and venture capital supply. The author argued that the annual long-term unemployment rate does not impact on venture capital. Félix et al. (2013) found that there is an inverse relationship between unemployment and venture capital supply. Similarly, Mishkin (2010) as well as Marti and Balboa (2001) also supported a negative association between unemployment and venture capital supply. Literature on unemployment and venture capital supply is inconclusive. This necessitates an investigation into the relationship between unemployment and venture capital supply. This study argues that during a period of high unemployment in an economy, the country becomes less attractive to the supply of venture capital fund because of high labour market rigidities, idle workers and idle resources; these set of circumstances are likely to lead to a lower output in the economy. It is on this basis that this study argues that there is a negative relationship between high unemployment and venture capital supply.

Foreign direct investment (FDI) and venture capital supply: A report by the World Bank (2011) amplified that FDI boosts economic growth of the home country by stimulating output and export. World Bank (2012) found that the FDI inflows to Sub-Sahara Africa focused more on natural resources. There is scarcity of literature on foreign direct investment as a determinant of venture capital supply. Notwithstanding, Agmon and Messica (2008) in a study carried out in Israel found that venture capitalist act as a financial and risk intermediaries and provide sector specific funds for financial foreign direct investment (FFDI). This study argues that countries with high foreign direct investment inflows are expected to be more attractive to the supply of venture capital fund. This study expects a positive relationship between FDI inflows and venture capital supply.

Inflation and venture capital supply: Bonini and Alkan (2009) revealed that higher level of inflation limits venture capital investments. Diaconu (2012) found that there is no significant connection between inflation and venture capital supply. It is expected that countries with high inflation are expected to discourage venture capital supply. During a period of high inflation, a country becomes less attractive to supply of venture capital fund because of the general increase in the price level. Inflation benefits debtors (borrowers) at the expense of the creditors (lenders). Inflation can also result in higher unemployment, lower economic growth and the balance of payments problems (Mohr \& Fourie, 2014; Muneer et al., 2017). Literature on the relationship between inflation rate and venture capital supply is inconclusive. However, most literature seem 
to support that there is an inverse relationship between high level of inflation in the economy and venture capital investment. It is on this basis that this study argues that there is a negative relationship between inflation and venture capital supply.

Trade openness and venture capital supply: There is scarcity of literature on trade openness as a determinant of venture capital supply. Countries with open economy are involved in international trade and finance (Mohr \& Fourie, 2014). This is measured by expressing the value of exports as a percentage of GDP. The authors further explain that globalisation can expand opportunities for people in an open economy through opening of new markets, greater production of traded goods, sharing of knowledge, increasing the efficiency of resources and an increase in economic welfare. This study argues that countries with high export are expected to be more attractive to venture capital supply because of the open economy and opportunities for opening new markets.

\section{Methodology}

Panel data techniques of pooled, fixed and random econometric procedures were employed. The model includes six determinants (IPO, market capitalisation, unemployment rate, foreign direct investment inflow, inflation rate and trade openness). In order to assess whether the six determinants have significant explanatory influence on venture capital supply in the eight Sub-Sahara African countries over the period 2006 to 2015 the panel data methodology was employed. Secondary data was utilised for the study. The primary sources of data were the World Bank Development indicators and Preqin data base. Eight countries (Botswana, Ivory Coast, Ghana, Kenya, Mauritius, Nigeria, South Africa and Uganda) and the period 2006 to 2015 were selected based on the availability of data on venture capital supply in Sub Saharan Africa. Panel data analysis is a form of longitudinal data analysis that determines the relationship between the variables of interest that have changed dynamically overtime. As explained by Bonini and Alkan (2006) the major advantage of panel data is that it permits to control for the individual heterogeneity, while increasing the number of freedom by linking cross sectional and time series data. In this study, the panel is a cross section of eight countries from Sub-Saharan Africa and the time dimensions include the period from 2006 to 2015. The panel data analysis supports regression analysis with both cross sectional and temporal measurement. The cross sectional measurement involves the eight (8) countries in Sub-Sahara Africa and the temporal dimension are the annual observations of a set of variables from 2006 to 2015 which is for ten (10) years. Therefore, the time series cross sectional data will contain a total of $8 * 10=80$ observations.

Panel data estimation: The research objective and hypotheses make it compulsory to establish a model on the determinants of venture capital supply. The choice of an appropriate model for this study creates some challenges because there are few studies on the determinants of venture capital supply. Due to this, this study will examine some of the models that have been used previously and then make a decision on the most appropriate model to be adopted. However, most of the studies have looked at both the demand and the supply side of venture capital activity. For example, Gompers and Lerner (1999) using a panel data from 1972 to 1994 in the U.S.A on venture capital fund raising identified the following factors on venture capital activity; IPO, GDP growth, research and development, capital gains tax rates, image in the form of firm's age and size and pension funds. Also, Romain and de la Potterie (2004) identified the factors of venture capital in sixteen (16) major Organisation for Economic Co-operation and Development (OECD) countries as GDP growth, interest rates, research and development, stock of knowledge, patents, corporate income tax rate and labour market rigidities. Gompers and Lerner (1999) model as well as Romain and de la Potterie (2004) model concentrated on the demand and supply side of venture capital activity. This makes the application of both models to be inappropriate for this study because the focus of this study is purely on venture capital supply.

Notwithstanding, Jeng and Wells (2000) using a panel data on twenty-one (21) OECD countries from the period 1986 to 1995 identified six factors on venture capital activity in U.S.A and Europe: (1) IPOs; (2) GDP and market capitalisation growth; (3) labour market rigidities; (4) accounting standards; (5) private pension funds and (6) government programme. Félix et al. (2013) using a panel data on twenty-three (23) European countries over a ten-year period identified the factors of European venture capital activity by extending the factors to include; the size of the merger and acquisition market, the market to book ratio and unemployment rate. Jeng and Wells (2000) model as well as Félix et al. (2013) model focused more on the venture capital 
supply. Both studies used the fixed effect and the random effect models. However, this study will extend the model to include pooled, fixed and random effect panel data models. The use of pooled, fixed and random effect panel data models allows the researcher to control endogeneity and to provide robust evidence on the model. The model for this study is depicted as follows:

Pooled model: The researcher will pool all the eighty (80) observations together and run the pooled panel data. The pooled panel assumes that all the eight countries are the same by using one intercept for all the countries but in reality the eight countries are not the same, although all the countries are in Sub-Sahara Africa. The main challenge with this model is that it does not differentiate between the eight countries. By pooling the eight countries it denies the heterogeneity that may exist among eight countries. The equation for the pooled panel data is depicted as follows:

Yit $=\alpha+\beta$ xit + Uit ;

equation

This model assumes that all the usual ordinary least square assumptions are not violated. The assumptions are; (1) $\alpha$ is not correlated with xit : E (xit $\alpha)=0$ and (2) xit is not correlated with Uit: E (xit Uit ) $=0$. The constant $(\alpha)$ is a constant across all countries and the effect of any of the factors IPO, market capitalisation, unemployment rate, FDI, inflation as well as trade openness is constant across all observations.

Fixed effect model: The Fixed effect model permits heterogeneity among the eight countries. Fixed effect model allows for the eight sampled counties to have their own intercept value. The intercept may vary across countries however the intercept may not differ over time. The intercept value for the fixed effect model is time invariant. The equation is shown below.

Yit $=\alpha i+\beta 1 x i t+U i t$;

equation

Where

Yit : is the dependent variable : venture capital supply, where $\mathrm{i}=$ country and $\mathrm{t}=10$ years from 2006 to 2015

$\alpha \mathrm{i}$ is the time invariant factor that affect Yit, often called fixed effect and the unknown intercept

$\beta 1$ : is the coefficient of the independent variable

xit : represents one independent variable, for example in this study it can represent any of the following factors: IPO, market capitalisation, unemployment rate, FDI, inflation rate and trade openness

Uit: is the error term also called idiosyncratic error because it comprises of unobserved factors that vary over time and affect Yit,

Alternatively, the fixed effects model can be used with binary variables. So the equation for the fixed effects model becomes: the fixed effect one way with the country effect: The equation for the fixed effect one way is shown below

Yit $=\beta 0+\beta 1 X 1 i t+\ldots+\beta k X k i t+Y 2 E 2+\ldots+$ YnEn + Uit

equation

Where

Yit : is the dependent variable : venture capital supply, where $i=$ country and $t=10$ years from 2006 to 2015

$\beta \mathrm{k}$ : is the coefficient for the independent variables, in this study it is the coefficient of any of the following factors: IPO, market capitalisation, unemployment rate, FDI, inflation rate and trade openness

Xkit: represents one independent variable, for example in this study it can represent any of the following factors: IPO, market capitalisation, unemployment rate, FDI, inflation rate and trade openness

Y2: Is the coefficient for the binary repressors, in this study it is the coefficient for any of the eight sampled countries: Botswana, Ivory Coast, Ghana, Kenya, Mauritius, Nigeria, South Africa, and Uganda.

En: is the entity n, in this study the countries. Since they are binary (dummies) entities is included in the model.

Uit: is the error term also known as idiosyncratic error because it comprises of unobserved factors that vary over time and affect Yit

The one way fixed effect panel allows for heterogeneity among the eight selected countries by allowing each country to have its own intercept value. The researcher added time effects to the country effects model to have a time and country fixed effects regression model: this is known as the fixed effect two-way model. The equation for the fixed effect two way is depicted below.

Yit $=\beta 0+\beta 1 X 1 i t+\ldots+\beta k X k i t+Y 2 E 2+\ldots+$ YnEn $+d 2 \mathrm{~T} 2+\ldots+d t T t+$ Uit $\quad$ equation 
Where

Yit : is the dependent variable : venture capital supply, where $i=c o u n t r y$ and $t=10$ years from 2006 to 2015 $\beta \mathrm{k}$ : is the coefficient for the independent variables, in this study it is the coefficient of any of the following factors: IPO, market capitalisation, unemployment rate, FDI, inflation rate and trade openness

Xkit: represents one independent variable, for example in this study it can represent any of the following factors: IPO, market capitalisation, unemployment rate, FDI, inflation rate and trade openness

Y2: Is the coefficient for the binary repressors, in this study it is the coefficient for any of the eight sampled countries: Botswana, Ivory Coast, Ghana, Kenya, Mauritius, Nigeria, South Africa, and Uganda.

En: is the entity $n$. in this study the countries. Since they are binary (dummies) entities is included in the model.

$\mathrm{dt}$ : countries

$\mathrm{Tt}$ : is time as binary variable (dummy) included in the model.

Uit: is the error term also known as idiosyncratic error because it comprises of unobserved factors that vary over time and affect Yit

The two way fixed effect panel permits heterogeneity among the eight selected countries by allowing each country to have its own intercept value and also allows for effects on time.

Random panel data: The random effect allows the eight countries have a joint mean value for the intercept. The equation is shown as follows:

Yit $=\beta$ xit $+\alpha+\mathrm{Uit}+\varepsilon i t$;

equation

Where

Yit : is the dependent variable : venture capital supply, where $i=c o u n t r y$ and $t=10$ years from 2006 to 2015

$\beta$ : is the coefficient for the independent variables, in this study it is the coefficient of any of the following factors: IPO, market capitalisation, unemployment rate, FDI, inflation rate and trade openness

Xit: represents one independent variable, for example in this study it can represent any of the following factors: IPO, market capitalisation, unemployment rate, FDI, inflation rate and trade openness

$\alpha$ : is the unknown intercept

Uit: represents the between entity (country) error

cit: is the within entity error

The random effect assumes that the country's error term is not connected with the predictors which allows for time invariant variables to play a role as explanatory variable.

Yit $=\beta 0+\beta 1 \mathrm{x} 1$ it $+\beta 2 \mathrm{X} 2 \mathrm{it}+\ldots \beta \mathrm{kXkit}+\mathrm{Uit}+$ eit

equation

Lastly, the following equation is the complete random effects model, which will describe the intensity of venture capital funds in an economy $\mathrm{i}$ in period $\mathrm{t}$ and it can be written in the log form capturing all the variables in this study:

$\log ($ VCS $)$ it $=\beta 0+\beta 1 \log ($ IPO $)$ it $+\beta 2 \log ($ market capitalisation $)$ it $+\beta 3 \log ($ Unemployment $)$ it $+\beta 4 \log ($ FDI $)+$ $\beta 5 \log$ (inflation rate) $+\beta 6 \log ($ tradeopen $)+U i t+\varepsilon i t$

equation

In equation (7), the parameters that are to be estimated are identified as follows:

VCS = Dependent variable (Venture capital supply)

$\beta 1=$ Independent variable (The impact of IPO)

$\beta 2=$ Independent Variable (The Impact of market capitalisation)

$\beta 3=$ Independent Variable (The Impact of Unemployment) and

$\beta 4=$ Independent Variable (The impact of FDI)

$\beta 5=$ Independent Variable (The impact of inflation rate)

$\beta 6=$ Independent Variable (The impact of trade openness)

This equation satisfies the 6 hypotheses.

Choosing between Fixed or Random effect model: For this study to choose between the fixed or the random effect model the Hausman test will be performed. The random effect model will be selected if the regressors are (insignificant $\mathrm{P}$-value, Probability $>$ Chi2

$>0.05)$. The formula for the Hausman test is shown below:

$\mathrm{W}=(\beta \mathrm{RE}-\beta \mathrm{FE}) \cdot \sum-1(\beta \mathrm{RE}-\beta \mathrm{FE}) \sim \operatorname{chi} 2(\mathrm{k})$ 
If $\mathrm{W}$ is insignificant ( $\mathrm{p}$-value $>5 \%$ ) the random effect model will be selected.

The result of Hausman test is presented in Table 1 below.

Table 1: Hausman test: the determinants of venture capital supply

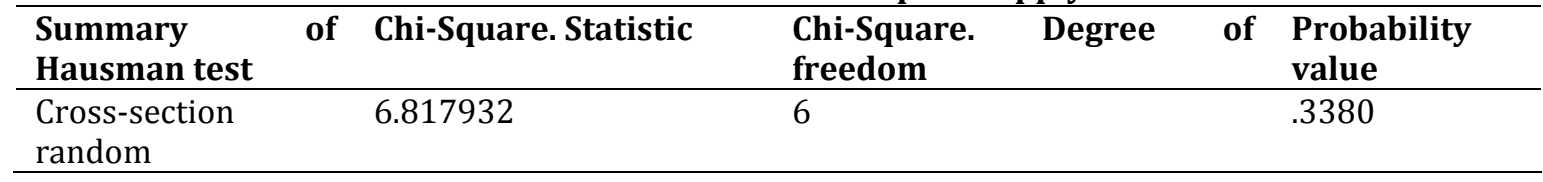

Table 1 shows that the random effect model was selected because the regressors are insignificant. The pvalue is $33.80 \%$. This is greater than $5 \%$; therefore the random effect model is the most appropriate. The results based on the random test will be presented in this paper and in Table 2.

\section{Results and Discussion}

Table 2 shows the result of the panel data using random effect two way for the determinants of venture capital.

Table 2: Panel data (Using random effect model two way)

\begin{tabular}{lllll}
\hline Factors & Coefficient & Std. Error & t-Statistic & probability \\
\hline C & 9.878627 & 56.20967 & 0.175746 & 0.8610 \\
IPO & 0.003288 & 0.001672 & 1.966442 & $0.0531^{*}$ \\
MKTCAP & 0.011712 & 0.003792 & 3.088669 & $0.0028^{* * *}$ \\
UNEMP & 0.014923 & 0.018719 & 0.797209 & 0.4279 \\
FDI & 0.960326 & 5.368799 & 0.178872 & 0.8585 \\
INFLATION & -0.624533 & 2.706329 & -0.230768 & 0.8181 \\
TRADEOPEN & -0.012457 & 0.010109 & -1.232312 & 0.2218 \\
Random Effects (Countries) & & & & \\
GHA & 0 & & & \\
KEN & 0 & & & \\
MUS & 0 & & & \\
NGA & 0 & & & \\
RSA & 0 & & & \\
UGA & 0 & & & \\
BWA & 0 & & & \\
CIV & 0 & & & \\
Random Effects (Period) & & & & \\
2006 & 0 & & & \\
2007 & 0 & & & \\
2008 & 0 & & & \\
2009 & 0 & & & \\
2010 & 0 & & & \\
2011 & 0 & & & \\
2012 & 0 & & & \\
2013 & 0 & & & \\
2014 & 0 & & & \\
2015 & 0 & & & \\
\hline
\end{tabular}

*** Significant at $1 \%$ and *significant at $10 \%$

The results from Table 2 indicate that there is a significant positive relationship between IPO and venture capital supply at $10 \%$. Furthermore, there is also a significant positive relationship between market capitalisation and venture capital supply at $1 \%$. These results are consistent with Félix et al. (2013). Table 3 presents a comparison of venture capital results with previous studies in literature. 
Table 3 depicts the six determinants of venture capital investigated in this study and their comparison with previous studies. This study found a significant positive relationship between IPO, market capitalisation and venture capital supply, this result is consistent with Félix et al. (2013). Furthermore, this paper found no relationship between unemployment, inflation and venture capital supply, this result is consistent with Diaconu (2012). There is paucity of literature to provide evidence on the relationship between FDI, trade openness and venture capital supply, notwithstanding this study found no relationship between FDI, trade openness and venture capital supply.

Table 3: Comparison of venture capital results with previous studies in literature

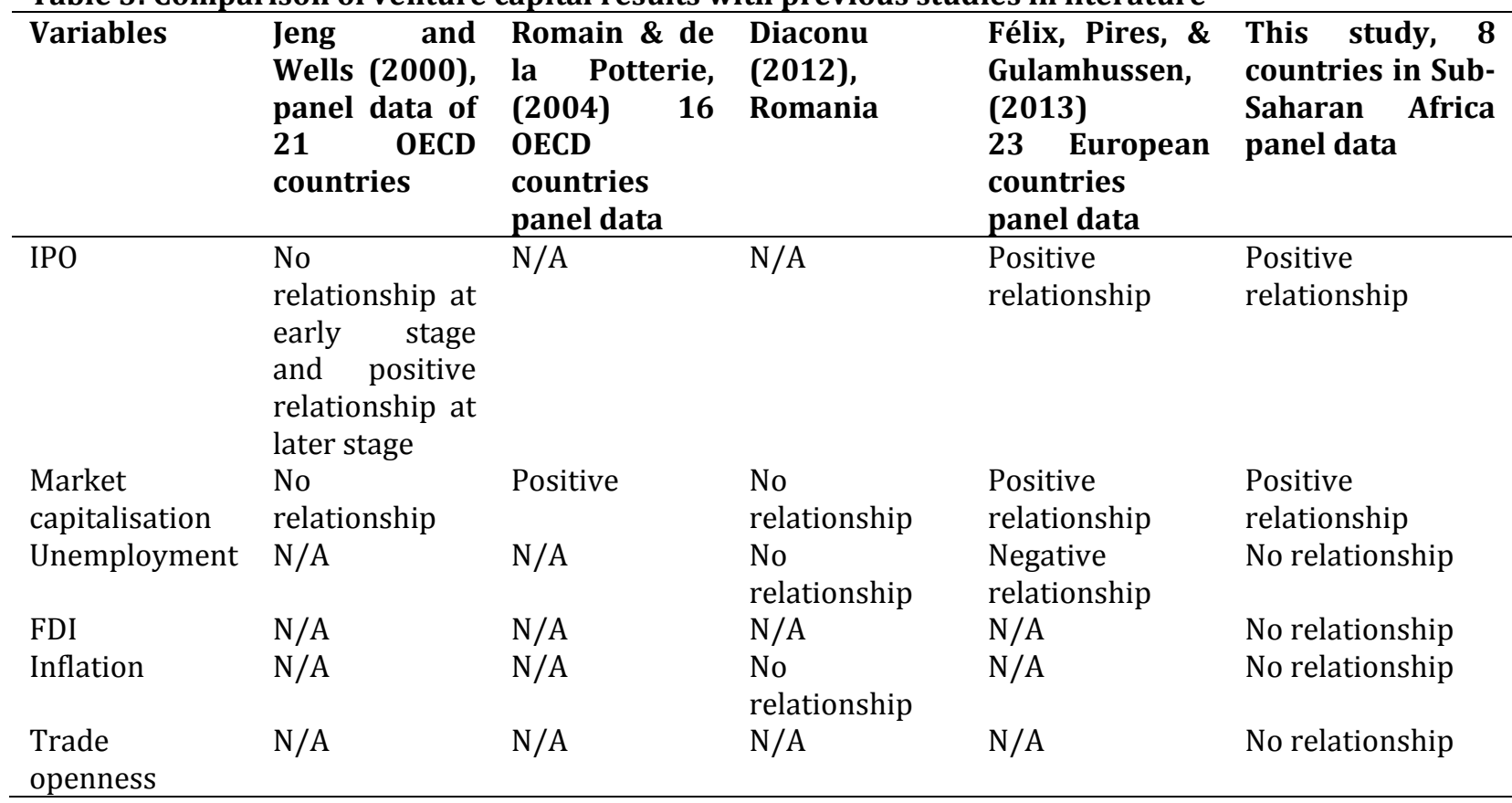

$\mathrm{N} / \mathrm{A}=$ Not Applicable

\section{Conclusion}

This section concludes a study that was undertaken to investigate the determinants of venture capital supply in Sub-Sahara Africa. This paper argues that the determinants of venture capital supply in developing countries are not only under explored, there is also conflicting evidence and in some instances inconclusive evidence on the relationship between the determinants of venture capital and venture capital supply. In accordance with this knowledge gap, this paper examined the determinants of venture capital supply in SubSahara Africa by means of pooled, fixed and random effects models on a data set of 8 countries for the period 2006 to 2015. The six variables (initial public offering, market capitalization, unemployment rate, FDI, inflation rate and trade openness) were tested on selected countries in Sub-Sahara Africa. The novelties of this paper are the inclusion of FDI and trade openness as determinants of venture capital supply. This paper found a significant positive relationship between IPO, market capitalization and venture capital supply. However, there is no significant relationship between unemployment rate, FDI inflows, inflation rate, trade openness and venture capital supply.

Recommendations: Based on the empirical findings of this study the following recommendations are proposed:

Infrastructure development and infrastructure policy: There is a need for Sub-Sahara African governments to develop their economies by improving infrastructure such as roads, rails, electricity and water supply. Venture capital investment in infrastructure is expected to generate job opportunities and inclusive growth in strategic sectors such as manufacturing, energy, technology, mining and agro-production. Sub-Sahara African countries should develop infrastructure policy and implement prioritised projects on time 
to prevent infrastructure backlog. It is high time for African leaders to collaborate and ensure intra-Africa development through regional economic integration. Regional economic integration is expected to make a significant contribution to Sub-Sahara Africa economy.

Business friendly policies and taxes: Additionally, the Sub-Sahara African governments should introduce business friendly policies; relax regulatory and other bureaucratic procedures to stimulate venture capital investments. For example, the pension funds can be utilised by encouraging pensioners to invest part of their pension funds in venture capital. This approach can be borrowed from United States and implemented in SubSahara African countries. Private pension funds are important source of venture capital funds. The study of Black and Gilson (1998) found that private pension funds provided $46 \%$ of venture capital money in the United States. In addition, a business friendly tax system will also encourage venture capital investment in Sub-Sahara Africa.

Equity market: Finally, the private sector should focus on the determinants of venture capital supply identified by this study to increase venture capital supply in Sub-Sahara African countries. Private sector should also create and use innovative ways of financing businesses bearing in mind the high rejection rates of banks for businesses because of collateral and interest. The following innovative finance methods are suggested by the study to facilitate venture capital finance (1) crowd pooling; (2) Islamic finance and (3) financial bootstrapping. Ramsey (2012) pointed out that crowd pooling is an innovative way of connecting investees with potential supporters using fundraising. Crowd pooling allows for raising capital for small businesses and to also test the marketability of the business. In addition, Lynn (2012) referred to crowd pooling as a new outgrowth of social media for providing finance for different ventures. According to The CityUK (2011) Islamic financial institutions recorded annual growth rates of $20 \%$ over the last decade because of innovative Islamic finance such as taxation structure that accommodates Islamic finance activities. Efforts were made to develop Islamic financial infrastructure directed towards guaranteeing better risk management and corporate governance. What can be concluded from the above is that crowd pooling, Islamic finance and financial bootstrapping are all innovative ways of adding value to venture capital finance in SubSahara Africa bearing in mind the high failure rate of private companies in Sub-Sahara Africa because of lack of collateral and high interest rates.

\section{References}

Adongo, J. (2011). Determinants of Venture Capital in Africa: Cross Section Evidence. AERC Research Paper, No. 237. African Economic Research Consortium, Nairobi.

African Private Equity and Venture Capital Association. (2013). Yearly archives: 2013, [Online]. Available:www.avca-africa.org/2013/page/2. [Retrieved on 31 December 2013].

Agmon, T. \& Messica, A. (2008). Venture capital funds, financial foreign direct investment and the generation of local comparative advantage in the technology sector in Israel. Contributions to Political Economy, 27(1), 57-72.

Agyeman, S. K. (2010). Challenges facing venture capitalists in developing economies: An empirical study about venture capital industry in Ghana.

Banerjee, A. (2008). Private equity in developing nations. Journal of Asset Management, 9(2), 158-170.

Black, B. S. \& Gilson, R. J. (1998). Venture capital and the structure of capital markets: banks versus stock markets. Journal of financial economics, 47(3), 243-277.

Bonini, S. \& Alkan, S. (2009). The macro and political determinants of venture capital investments around the world. Available at SSRN 945312.

Chang, S. J. (2004). Venture capital financing, strategic alliances, and the initial public offerings of Internet startups. Journal of Business Venturing, 19(5), 721-741.

Chemmanur, T. J. \& Chen, Z. (2006). Venture capitalists versus angels: the dynamics of private firm financing contracts.

Cherif, M. \& Gazdar, K. (2011). What drives venture capital investments in Europe? New results from a panel data analysis. Journal of Applied Business and Economics, 12(3), 122-139.

Clarysse, B., Knockaert, M. \& Wright, M. (2009). Benchmarking UK venture capital to the US and Israel: what lessons can be learned. Report for British Private Equity and Venture Capital Association. 
Da Rin, M., Nicodano, G. \& Sembenelli, A. (2006). Public policy and the creation of active venture capital markets. Journal of Public Economics, 90(8), 1699-1723.

Diaconu, M. (2012). Characteristics and drivers of venture capital investment activity in Romania. Theoretical \& Applied Economics, 19(7).

Ecer, S. \& Khalid, S. (2013). Stage-specific effects of the Sarbanes-Oxley Act. Journal of Entrepreneurship and Public Policy, 2(2), 110-129.

Emerging Markets Private Equity Association. (2013). How to Win Big Returns in Africanprivateequity.[Online].Available:http://www.africancapitalmarketsnews.com/tag/emergingmarkets-private-equity-association/. [Retrieved on 26 March 2015].

Johnson, S. (2010). Emerging Markets Take Record Share of Private Equity. [Online]. Available: htttp://www.ftcom/cms/s/0/8c6ca37e-9681-11df-9caa-00144feab49a.html. [Retrieved on 5 August 2013].

Félix, E. G. S., Pires, C. P. \& Gulamhussen, M. A. (2013). The determinants of venture capital in EuropeEvidence across countries. Journal of Financial Services Research, 44(3), 259-279.

Gompers, P. A., \& Lerner, J. (1999). What drives venture capital fundraising? (No. w6906). National bureau of economic research.

Gompers, P. \& Lerner, J. (1998). Venture capital distributions: Short-run and long-run reactions. The Journal of Finance, 53(6), 2161-2183.

Harris, M. \& Raviv, A. (1991). The theory of capital structure. The Journal of Finance, 46(1), 297-355.

Henderson, R. M. \& Newell, R. (2011). Introduction and Summary. Accelerating Energy Innovation: Insights from Multiple Sectors.

Iqbal, S. M. J., Muneer, S., Jahanzeb, A. \& Rehman, S. U. (2012). A Critical Review of Capital Structure Theories. Information Management and Business Review, 4(11), 553-557

Jeng, L. A. \& Wells, P. C. (2000). The determinants of venture capital funding: evidence across countries. Journal of corporate Finance, 6(3), 241-289.

Jensen, M. C. \& Meckling, W. H. (1976). Theory of the firm: Managerial behavior, agency costs and ownership structure. Journal of financial economics, 3(4), 305-360.

Kelly, R. (2012). Drivers of private equity investment activity: are buyout and venture investors really so different? Venture Capital, 14(4), 309-330.

Kuratko, D. F. \& Hodgetts, R. M. (2007). Entrepreneurship: A Contemporary Approach, (7th ed), London: Thomson/South-Western.

Lebus, M. (2013). Africa under the venture capital spotlight. The next woman.

Lynn, D. M. (2012). The crowdfunding provisions of the JOBS Act. Financial Executive, 28(4), 42-44.

Marti, J. \& Balboa, M. (2001). Determinants of private equity fundraising in Western Europe. In Social Science Research Network Working Paper, presented at the EFMA 2001 Lugano Meetings.

Mishkin, F. S. (2010). The Economics of Money, Banking, and Financial Markets ( $9^{\text {th }}$ ed), Pearson Prentice Hall: Upper Saddle River, New Jersey.

Modigliani, F. \& Miller, M. H. (1958). The cost of capital, corporation finance and the theory of investment. The American economic review, 48(3), 261-297.

Mohr, P. \& Fourie, L. (2014). Economics for South African Students (5 ${ }^{\text {th }}$ ed), Van Schaik publishers. Hatfield, Pretoria.

Muneer, S., Bajuri, N. H. \& Rehman, S. U. (2013). Moderating Effect of Agency Cost on the Relationship between Capital Structure, Dividend Policy and Organization Performance: A Brief Literature Review. Actual Problems of Economics, 11(149), 434-442

Muneer, S., Tufail, M. S., Jamil, K. \& Zubair, A. (2017). Impact of Capital Market Expansion on Company's Capital Structure. NFC-IEFR Journal of Engineering and Scientific Research, 5, 1-7

Myers, S. C. (1984). The capital structure puzzle. The journal of finance, 39(3), 574-592.

Msweli, P. \& Oni, O. (2014). The Link between Venture Capital Supply Factors and Economic Development in South Africa. Mediterranean Journal of Social Sciences, 5(9), 18.

Nieman, G. (2006). Small Business Management (1'st ed), Hatfield, Pretoria: Van Schaik.

Ramsey, Y. A. (2012). What the heck is crowd funding. Business people, 25(11), 54-57.

Romain, A. \& de la Potterie, B. V. P. (2004). The determinants of venture capital: a panel data analysis of 16 OECD countries〉, Centre Emile Bernheim, Research Institute in Management Science. Working Paper, (04/015), April. 


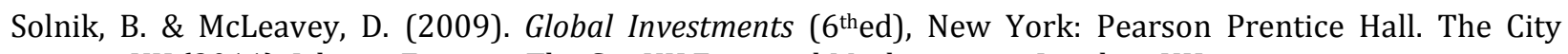
UK,(2011). Islamic Finance. The CityUK Financial Market series. London: UK.

Van Deventer, B. \& Mlambo, C. (2009). Factors influencing venture capitalists' project financing decisions in South Africa. South African Journal of Business Management, 40(1), 33-41.

Ventures Africa. (2013). African PE Funds Outperformed US Venture Capital. Cambridge. [Online]. Available: http://www.ventures-africa.com/2013/04/african-pe-funds-outperformed-us-venture-capitalcambridge/. [Retrieved on 30 March 2015].

World Bank. (2011). World Bank Annual Report. [Online]. Available: https://openknowledge.worldbank.org/handle/10986/4389. [Retrieved on 30 March 2015].

World Bank. (2012). FDI from Developing and Transition Economies: Implications for Development, World Investment Report. [Online]. Available: unctad .org /en / Publications Library / wir2012overview_en.pdf. [Retrieved on 26 March 2015]. 